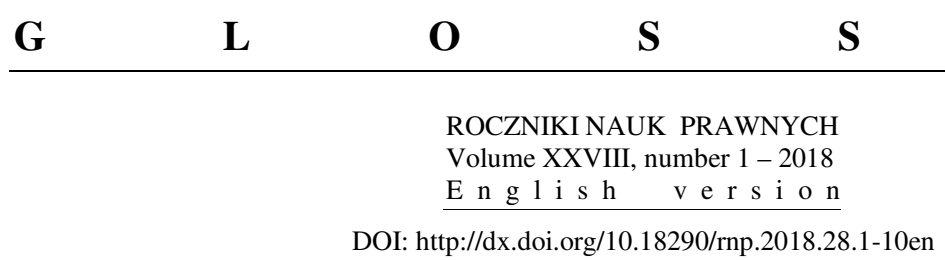

SŁAWOMIR JOACHIMIAK

\title{
A GLOSS FOR THE JUDGEMENT OF THE SUPREME COURT \\ OF 22 JUNE 2017, FILE REF. NO. IV KK 189/17*
}

\section{PROPOSITION}

The imposition of an absolute concurrent sentence of imprisonment is at conflict with the expungement of an individual custodial sentence having a relative character, that is an event under Article $76 \S 1$ of the Polish Penal Code. Therefore, the suspended custodial sentence would be enforced as part of a concurrent sentence, in fact as an absolute sentence, even though the probationary period and six consecutive months have expired. Article $76 \S 1$ explicitly prohibits such conduct.

The subject of the Supreme Court's adjudication was the possibility of subsuming a suspended custodial sentence under a concurrent sentence, after the expiry of the probationary period and the following 6 months. The Supreme Court assumed that "the imposition of an absolute cumulative penalty of imprisonment is impeded by the expungement of an individual custodial sentence, which has a relative character thus falling under Article $76 \S 1$ of the Penal Code [henceforth abbreviated as PC]. In such a situation, the suspended custodial sentence would be enforced as part of a concurrent

\footnotetext{
SŁaWomir Joachimiak, PhD, is an assistant district prosecutor in Kalisz, Poland; e-mail: joachimiak1@wp.pl.

* Published in LEX no. 2361647; the proposition published in Prokuratura i Prawo-inset 2017, no. 9, item 3 .
} 
judgement, as in fact a penalty of an absolute character, even though the probationary period and six consecutive months have expired. Article $76 \S 1$ PC explicitly forbids such conduct.

\section{FACTS}

In one concurrent sentence dated September 28, 2016 (file ref. no. III K [...]), the District Court in G. combined the sentences imposed on convicted M.G. by the following judgements: Judgement of the District Court in G. of 24 October 2011, file ref. no. IX K [...]/10, Judgement of the District Court in $\mathrm{G}$ of 13 December 2011, file ref. no. III K [...]/11, Judgement of the District Court in S. of 28 February 2012, file ref. no. II K [...]/11, Judgement of the District Court in G. of 14 August 2012, file ref. no. IX K [...]/12, Judgement of the District Court in G. of 29 October 2012, file ref. no. IX K [...]/10, Judgement of the District Court in G. of 29 January 2014, file ref. no. IX K [...]/13, Judgement of the District Court in G. of 25 June 2015, file ref. no. III K $[\ldots] / 14$, and pronounced a concurrent sentence of 3 years and 6 months of imprisonment. This ruling became final, uncontested by either party. The cassation against the judgement was filed by the Minister of Justice - Public Prosecutor General in favour of the convicted person, who pointed out a gross and significant violation of provisions of Article $85 \S \mathrm{PC}$ in relation to Article $89 \S 1 \mathrm{a} \mathrm{PC}$ in relation to Article $75 \S 4 \mathrm{PC}$ in relation to Article $569 \S 1$ of the Code of Criminal Procedure consisting in including the individual suspended sentence of 8 months' imprisonment with its execution suspended for a period of 2 years of probation in the concurrent sentence imposed by the judgement of the District Court in G. of 13 December 2011, file ref. no. III K [...]/11, despite the fact that the time limit for its execution has expired, and thus the penalty could not be enforced and combined. In support of his claims, the complainant requested that the contested judgement be reversed and that the case be remanded for reconsideration.

The Supreme Court made a legitimate ruling considering the complainant's application in its entirety. However, the clarification of its legal basis does not seem to be sufficient. 


\section{EXISTING LEGISLATION}

The point of departure for the consideration of the case was the provision of Article $89 \S 1$ a PC providing that in the event of a conviction of concurrent crimes punishable by imprisonment with a conditional suspension of their execution, the court may, pronounce a concurrent custodial sentence which is not conditionally suspended. This provision supplements Article 89 $\S 1 \mathrm{PC},{ }^{1}$ providing for the possibility of conditionally suspending a concurrent sentence in the case of a conviction for concurrent crimes both punishable conditionally by imprisonment and without conditional suspension under Article $69 \S 1$ PC.

Referring to Article $76 \S 1 \mathrm{PC}$, providing for expungement by operation of law within 6 months from the end of probationary period, the Supreme Court assumed that with the expiration of that period it is not possible to include a conditionally suspended sentence with a concurrent sentence. Such reasoning implies that the reason for excluding the application of the provision of Article $89 \S 1$ a PC-with the conditions of Article $76 \S 1$ PC fulfilled-is expungement causing the imposition of a sentence to be deemed null and void.

In its reasoning for the ruling of June 22, 2017, the Supreme Court passed over the legislative changes that had occurred in the provision of Article 76 PC in the period between the imposition of the individual sentences included the contested combined sentence and the imposition of a cassation sentence, including two amendments to the provision of Article $76 \S 1$ PC. The Court did not address in any way the content of the provision of Article $76 \S 1 \mathrm{~b}$ PC, in force since April 15, 2016, ${ }^{2}$ which was also in force when the concurrent sentence was handed down by the District Court (September 28, 2016) in the case in which a cassation was subsequently filed by the Minister of Justice-Public Prosecutor General. This provision indicates that in the case referred to in Article $76 \S 1$ PC (i.e. expungement by operation of law after the lapse of 6 months from the end of the probational period), the provision

\footnotetext{
${ }^{1}$ In the case at hand, it should be assumed that the Supreme Court ruled within the legal framework which was in force as of July 1, 2015 and within the scope of Chapter 9 of the Penal Code, taking into account the content of Article 19 para. 1 of the Act of 20 February 2015 amending the Penal Code and certain other acts, Journal of Laws No. 396, and the fact that Judgement of the District Court in G. of 25 June 2015 file ref. no. III K [...]/14 could become final only after July 1, 2015.

${ }^{2}$ Added by Act of 11 March 2016 amending the Code of Criminal Procedure and certain other acts, Journal of Laws of 2016, item 437.
} 
of Article 108 PC applies, providing for an obligatory simultaneous erasion of all convictions in a situation where the perpetrator has been convicted of two or more non-concurrent offences, as well as in a situation where a convicted person, after the commencement but before the expiry of the period required for expungement, commits an offence again. In principle, as noted in the justification of the draft, the provision clarifies the relationship between the provisions of Articles $76 \S 1$ and $108 \mathrm{PC}$, clearly indicating that in a situation specified in Article $76 \S 1$ PC the provision of Article $108 \mathrm{PC}$ finds its application. ${ }^{3}$ It (Article $76 \S 1 \mathrm{~b}$ PC) therefore supplements the normative content of the provision of Article $76 \S 1 \mathrm{PC}$, which cannot be construed correctly without it (i.e. Article $76 \S 1 \mathrm{~b}$ PC). The content of Article $76 \S 1 \mathrm{PC}$ was also omitted from the ruling at hand in its wording in force from July 1, 2015 to April 14, 2016, ${ }^{4}$ that is in the period between the issuance of individual sentences and the concurrent sentence of the District Court in G. The third sentence of the said article explicitly implied that for the conviction to be expunged under Article $76 \S 1$ sentence 1 PC, Article 108 PC applies, so it is only possible to erase all convictions against the perpetrator. It is wrong to think ${ }^{5}$ that after July 1,2015 , due to the content of Article $76 \S \mathrm{PC}^{6}{ }^{6}$ the phrase that "the provision of Article 108 is applied," was valid only in the situation mentioned in Article 75a PC, i.e. ordering the enforcement of a fine or restriction of liberty instead of ordering the enforcement of a penalty of imprisonment. Unjustifiably, it was assumed that the content of the third sentence of the provision of Article $76 \S 1$ PC referred only to the object of regulation of Article $76 \S 1$ sentence 2 PC, but not to the object of regulation of Article $76 \S 1$ sentence 1 PC, which concerns, after all — and this probably does not raise any doubts — having the penalty

\footnotetext{
${ }^{3}$ See Uzasadnienie projektu ustawy o zmianie ustawy-Kodeks postepowania karnego oraz niektórych innych ustaw, 8th Sejm of the Republic of Poland, Sejm Paper no. 207. For a similar interpretation, see Judgement of the Supreme Court of 8 November 2016, file ref. no. V KK 265/16, LEX no. 2148674. For a different interpretation, see Judgement of the Supreme Court of 12 October 2016, file ref. no. V KK 178/16, LEX no. 2142041.

${ }^{4}$ Given by Act of 20 February 2015 amending the Penal Code and certain other acts.

${ }^{5}$ Expressed by the Supreme Court in its judgement dated October 12, 2016, file ref. no. V KK 178/16, and by Kazimierz Postulski in his gloss for the judgement of the Supreme Court dated February 13, 2015, file ref. no. II K 194/14, LEX 2015; S. HYPŚ, "Komentarz do artykułu 76," in Kodeks karny. Komentarz, ed. A. Grześkowiak and K. Wiak (Warszawa: Wydawnictwo C.H. Beck, 2015), 528-29.

${ }^{6}$ Which provided that: "A conviction shall be erased by operation of law six months after the end of the probationary period. In cases referred to in Article 75a, expungement takes place after the lapse of periods provided for in art. $107 \S 4$ and 4a. The provision of Article 108 shall apply."
} 
executed both under Article $75 \mathrm{PC}$ and Article 75a PC. ${ }^{7}$ The application of the provision of Article 76 sentence $3 \mathrm{PC}$ also to Article $76 \S 1$ sentence 1 $\mathrm{PC}$ is indirectly supported by the said amendment of Article 76 PC, which as of April 15, 2016 retained only the first sentence from the previously binding version of Article $76 \S 1 \mathrm{PC}$, while the phrase concerning the application of Article 108 PC was transferred to a separate unit of text in the form of $\S$ $1 \mathrm{~b}$, which clearly indicates that the order to apply Article 108 PC also covers the case referred to in Article $76 \S 1 \mathrm{PC}$, that is expungement by operation of law within 6 months of the end of the probationary period. Practically, this amendment left the normative content of the provisions unchanged, making only editorial changes to them to render them more intelligible.

Therefore, if in the case at hand Article 76 PC was applied in its wording valid as of July 1, 2015, it should be assumed that expungement in the case decided by an individual judgement of the District Court in G. of 13 December 2011, file ref. no. III K [...]/11 did not take place. This would create a dilemma whether the penalty whose enforcement cannot be ordered for the reasons indicated in Article $75 \S 4 \mathrm{PC}^{8}$ (therefore, in fact, it is not possible to enforce it) can be included in a concurrent sentence.

In case IV KK 189/17 adjudicated by the Supreme Court it should be assumed-despite the categorical statement in the justification regarding the scope of application of Article $76 \S 1$ PC without any reference to its amendment - that this provision in the aforementioned wording could not be applied due to the content of the transitional provision, namely Article 21, sentence 1 of the Act of 20 February 2015 amending the Penal Code and certain other acts, which lays down that convictions handed down by final judgements before July 1, 2015 shall be subject to the provisions of the Penal Code in the wording provided by this law, unless the period of expungement expired before that date. There should be no doubt that the reviewed judgement of the District Court in G. of December 13, 2011 (ref. no. III K [...]/ 11), passing a sentence of 8 months of imprisonment with a conditionally suspended execution for a probationary period of two years, was expunged before July 1, 2015, when the probationary period and 6 months after its completion had expired by that time. At that time, there was no specific regulation defining the relationship between the provisions of Articles 76 and

\footnotetext{
${ }^{7}$ Compare S. TARAPATA, "Przedawnienie i zatarcie skazania," in Nowelizacja prawa karnego 2015. Komentarz, ed. W. Wróbel (Kraków: Krakowski Instytut Prawa Karnego, 2015), 821-22.

${ }^{8}$ Which lays down that "the ordering of penalty enforcement may not be done more than six months after the end of the probationary period."
} 
$108 \mathrm{PC}$. The dominant view was that Article $76 \S 1 \mathrm{PC}$ has characteristics of lex specialis in relation to Article $108 \mathrm{PC},{ }^{9}$ although this opinion has been challenged by jurisprudence at times. ${ }^{10}$ It has been pointed out that the convicted persons facing a conditionally suspended penalty enjoy unjustified privilege. ${ }^{11}$ The adoption of the view that Article 76 PC was a special provision in relation to Article $108 \mathrm{PC}$ gave rise to a situation that for expungement no simultaneous fulfilment of expungement conditions was required for all convictions hereto not erased-after the probationary period and the consecutive 6 months had expired. Therefore, having regard to the content of Article $76 \S 1$ PC in the version in force until June 30, 2015 in conjunction with Article 21 of the act of February 20, 2015, it had to be assumed without indicating any transitional provisions-what in fact the Supreme Court did - that by judgement of the District Court in case III K [...]/ 11 the conviction was subject to erasure and it was not possible to include it in a consecutive sentence due to the use of legal fiction of a non-existent conviction.

It may seem in the case at hand that the reason for the Supreme Court's adjudication on the impossibility of including in one concurrent sentence a conviction for which the probationary period and 6 months after its completion have already expired, was not only the provision of Article $76 \S 1$ PC but also the provision of Article $75 \S 4$ PC, which may be inferred from the cassation charge-violation of Article $85 \S 2$ PC in connection with

\footnotetext{
${ }^{9}$ Compare Judgement of the Supreme Court of 17 May 2000, file ref. no. V KKN 104/00, LEX no. 50954; Judgement of the Supreme Court of 11 March 2010, file ref. no. IV KK 396/09, Orzecznictwo Sadu Najwyższego w Sprawach Karnych (2010), no. 1, item 540; Judgement of the Supreme Court of 29 August 2013, file ref. no. IV KK 168/13, Orzecznictwo Sąu Najwyższego Izba Karna i Izba Wojskowa (2013), no. 12, item 107; Judgement Supreme Court of 16 December 2014, file ref. no. V KK 367/14, Prokuratura i Prawo, inset (2015), no. 4, item 2; B. STEFAŃsKA, "Zatarcie warunkowego skazania," Prokuratura i Prawo 7-8 (2009): 120-21; IDEM, Zatarcie skazania (Warszawa: Wolters Kluwer, 2014), 257; J. LACHOWSKI, "Komentarz do artykułu 76," in Kodeks karny. Część ogólna, ed. M. Królikowski and R. Zawłocki (Warszawa: Wydawnictwo C.H. Beck, 2015), 2:409; Judgement of the Supreme Court of 13 February 2015, file ref. no. II KK 194/14, Prokuratura i Prawo, inset (2015), no. 5, item 5; Judgement of the Supreme Court of 12 October 2016, file ref. no. V KK 178/16; Judgement of the Supreme Court of 8 November 2016, file ref. no. V KK 265/16, LEX no. 2148674; for some doubts in this regard, see also M. BŁASZCZYK, "Komentarz do artykułu 108," in Kodeks karny. Część ogólna, 2: 686-88; G. BoGDAN, "Komentarz do artykułu 108," in Kodeks karny. Część ogólna, ed. W. Wróbel and A. Zoll (Warszawa: Wolters Kluwer, 2016), 1:874-76; compare also J. MAJEwsKI, Kodeks karny. Komentarz do zmian 2015 (Warszawa: Wolters Kluwer, 2015), 280.

${ }^{10}$ Compare MAJEwSKI, Kodeks karny, 280; S. TARAPATA, "Kilka uwag na temat nowelizacji przepisów kodeksu karnego dotyczących instytucji przedawnienia oraz zatarcia skazania," Palestra 7-8 (2015): 142; BoGDAN, "Komentarz do artykułu 108," 874-76.

${ }^{11}$ Compare MAJEwsKI, Kodeks karny, 280.
} 
Article $89 \S 1$ a PC in connection with Article 75 § 4 PC in connection with Article $569 \S 1$ of the Code of Criminal Procedure-which was taken into account in its entirety. For this reason, I have already pointed out the problem boiling down to the question whether a penalty the enforcement of which for the reasons indicated in Article 75 § 4 PC cannot be ordered, can be included in concurrent sentence. This issue is extremely important for judicial practice in the context of the provisions on cumulative penalty regulated in Article 85 of the amended Penal Code in conjunction with Articles 76 and 108 PC. It may happen that the perpetrator will be sentenced to imprisonment with conditional suspension of their execution, whose probationary periods plus the consecutive 6 months have expired, and then, due to the categorical content of the provision of Article $85 \S 1 \mathrm{PC}$, it will be necessary to hand down a concurrent sentence. It does not seem sufficient to state that it is not possible to include such a penalty in a concurrent sentence due to the content of Article $76 \S 1 \mathrm{PC}$, as this is contradicted by the content of Article $76 \S 1 \mathrm{~b}$ PC in relation to Article 108 PC.

Therefore, despite the fact that the inclusion of such a penalty in a concurrent sentence would give rise to a manifestly unfavourable situation of the convicted person since a conditionally suspended sentence-the execution of which cannot be ordered-would be subject to concurrence, it must be assumed that such a penalty should be covered by a concurrent sentence. On the one hand, the Penal Code indicates the necessity of issuing a concurrent sentence in a situation where the perpetrator has committed two or more crimes and penalties of the same type or others subject to accumulation have been administered, on the other hand, there is no provision which would enable a withdrawal from this firm disposition in a situation where the probationary period and 6 months from its termination have expired in relation to the conditionally suspended custodial sentence. Therefore, it should be assumed that in a case where a conditionally suspended sentence, the execution of which was not ordered within the probationary period and the consecutive 6 months, meets the requirements of Article $85 \S 1$ PC and should be covered by a concurrent sentence. For such an interpretation of relevance is the fact that a cumulative penalty is not intended, as it were, to improve the situation of the sentenced person in terms of the penalty to be enforced, but is intended solely - on the basis of the directives of its imposition-to reassess the amount of the penalty, irrespective of its limits, either lower or upper limits of the penalties subject to accumulation. In this respect, we should share the opinion that the view which is prevalent in jurisdiction and jurisprudence that imposition of a cumulative penalty by a concurrent 
sentence must not deteriorate the convicted person's status was developed on the basis of the provisions of the Penal Code of 1969, which did not include the regulation of Article 89, provided for in the new Penal Code. There is nothing to prevent us from believing that the legislator, when introducing this normative provision, deliberately assumed that the imposition of a cumulative penalty may in certain circumstances exacerbate the situation of the convicted person. ${ }^{12}$

\section{BIBLIOGRAPHY}

\section{SOURCES OF LAW}

Ustawa z dnia 20 lutego 2015 r. o zmianie ustawy-Kodeks karny oraz niektórych innych ustaw [Act of 20 February 2015 amending the Penal Code and certain other acts], Journal of Laws of 2015 , item 396.

Ustawa z dnia 11 marca 2016 r. o zmianie ustawy-Kodeks postępowania karnego oraz niektórych innych ustaw [Act of 11 March 2016 amending the Code of Criminal Procedure and certain other acts], Journal of Laws of 2016, item 437.

\section{CASE LAW}

Resolution of the Supreme Court of 25 April 2005, file ref. no. I KZP36/04, Orzecznictwo Sadu Najwyższego Izba Karna i Izba Wojskowa (2012), no. 2, item 13.

Judgement of the Supreme Court of 17 May 2000, file ref. no. V KKN 104/00, LEX no. 50954.

Judgement of the Supreme Court of 3 June 2009, file ref. no. III KK 27/09, Prokuratura i Prawo, inset (2009), nos. 11-12, item 4.

${ }^{12}$ See Decision of the Supreme Court of 1 October 2002, file ref. no. V KK 73/02, LEX no. 56827; D. KalA, Postepowanie w przedmiocie wydania wyroku tacznego. Zagadnienia karnomaterialne i procesowe (Toruń: Towarzystwo Naukowe Organizacji i Kierownictwa „Dom Organizatora", 2003), 150; Resolution of the Supreme Court of 25 February 2005, file ref. no. I KZP 36/04, Orzecznictwo Sadu Najwyższego Izba Karna i Izba Wojskowa (2005), no. 2, item 13, which was given the status of a legal principle; Decision of the Supreme Court of 4 July 2007, file ref. no. V KK 419/06, Orzecznictwo Sąu Najwyższego Izba Karna i Izba Wojskowa (2007), no. 10, item 74; Decision of the Supreme Court of 24 August 2012, file ref. no. III KK 52/12, Krakowskie Zeszyty Sąowe (2012), no. 12, item 19; A. RYBAK-STARCZAK, "Kara łączna z warunkowym zawieszeniem wykonania kary," Probacja 1 (2011): 133-35; S. ŻóŁteK, "Zbieg przestępstw oraz łączenie kar i środków karnych,” in Kodeks karny. Część ogólna, 2:471-547; see, however, Judgement of the Supreme Court of 3 June 2009, file ref. no. III KK 27/09, Prokuratura i Prawo, inset (2009), nos. 11-12, item 4. Compare also the view presented by Tomasz Całkiewicz on the general principle banning the aggravation of the situation of a convicted person when imposing a combined penalty, subject to restrictions resulting from, among others, Article $89 \S 1 \mathrm{PC}$ - that is to say when combining a custodial sentence with and without a conditionally suspended enforcement, T. CAŁKIEWICZ, "Dyrektywy wymiaru kary łącznej orzekanej wyrokiem łącznym," Palestra 7-8 (2006): 72-73. 
Judgement of the Supreme Court of 11 March 2010, file ref. no. IV KK 396/09, Orzecznictwo Sąu Najwyższego w Sprawach Karnych (2010), no. 1, item 540.

Judgement of the Supreme Court of 29 August 2013, file ref. no. IV KK 168/13, Orzecznictwo Sąu Najwyższego Izba Karna i Izba Wojskowa (2013), no. 12, item 107.

Judgement of the Supreme Court of 16 December 2014, file ref. no. V KK 367/14, Prokuratura i Prawo, inset (2015), nos. 4, item 2.

Judgement of the Supreme Court of 13 February 2015, file ref. no. II KK 194/14, Prokuratura $i$ Prawo, inset (2015), nos. 5, item 5.

Judgement of the Supreme Court of 12 October 2016, file ref. no. V KK 178/16, LEX no. 2142041.

Judgement of the Supreme Court of 8 November 2016, file ref. no. V KK 265/16, LEX no. 2148674 .

Judgement of the Supreme Court of 22 June 2017, file ref. IV KK 189/17, LEX no. 2361647.

Decision of the Supreme Court of 1 October 2002, file ref. no. V KK 73/02, LEX no. 56827.

Decision of the Supreme Court of 4 July 2007, file ref. no. V KK 419/06, Orzecznictwo Sadu Najwyższego Izba Karna i Izba Wojskowa (2007), no. 10, item 74.

Judgement of the Supreme Court 25 April 2012, file ref. no. III KK 52/12, Krakowskie Zeszyty Sadowe (2012), no. 12, item 19.

\section{LITERATURE}

BŁASZCZYK, Magdalena. "Komentarz do artykułu 108." In Kodeks karny. Część ogólna, edited by Michał Królikowski and Robert Zawłocki, 2:686-88. Warszawa: Wydawnictwo C.H. Beck, 2015.

BogDAN, Grzegorz. "Komentarz do artykułu 108." In Kodeks karny. Część ogólna, edited by Włodzimierz Wróbel and Andrzej Zoll, 1: 874-76. Warszawa: Wolters Kluwer, 2016.

CAŁKIEwICZ, Tomasz. "Dyrektywy wymiaru kary łącznej orzekanej wyrokiem łącznym." Palestra 7-8 (2006): 66-81.

HyPś, Sławomir. "Komentarz do artykułu 76." In Kodeks karny. Komentarz, edited by Alicja Grześkowiak and Krzysztof Wiak, 528-29. Warszawa: Wydawnictwo C.H. Beck, 2015.

KALA, Dariusz. Postepowanie w przedmiocie wydania wyroku tącznego. Zagadnienia karnomaterialne i procesowe. Toruń: Towarzystwo Naukowe Organizacji i Kierownictwa „Dom Organizatora", 2003.

LACHOWSKI, Jerzy. "Komentarz do artykułu 76.” In Kodeks karny. Część ogólna, edited by Michał Królikowski and Robert Zawłocki, 2: 409. Warszawa: Wydawnictwo C.H. Beck, 2015.

MAJEWSKI, Jarosław. Kodeks karny. Komentarz do zmian 2015. Warszawa: Wolters Kluwer, 2015.

PostUlSKI, Kazimierz. Glosa do wyroku SN z dnia 13.02.2015 r., II K 194/14, LEX 2015.

RYBAK-STARCZAK, Agnieszka. "Kara łączna z warunkowym zawieszeniem wykonania kary." Probacja 1 (2011): 122-35.

STEFAŃSKA, Blanka. Zatarcie skazania. Warszawa: Wolters Kluwer, 2014.

STEFAŃSKA, Blanka. "Zatarcie warunkowego skazania.” Prokuratura i Prawo 7-8 (2009): 115-23.

TARAPATA, Szymon. "Kilka uwag na temat nowelizacji przepisów kodeksu karnego dotyczących instytucji przedawnienia oraz zatarcia skazania." Palestra 7-8 (2015): 133-43. 
TARAPATA, Szymon. "Przedawnienie i zatarcie skazania." In Nowelizacja prawa karnego 2015. Komentarz, edited by Włodzimierz Wróbel, 821-22. Kraków: Krakowski Instytut Prawa Karnego, 2015.

Uzasadnienie projektu ustawy o zmianie ustawy-Kodeks postępowania karnego oraz niektórych innych ustaw, $8^{\text {th }}$ Sejm of the Republic of Poland, Sejm Paper no. 207.

ŻóŁTEK, Sławomir. "Zbieg przestępstw oraz łączenie kar i środków karnych.” In Kodeks karny. Część ogólna, edited by Michał Królikowski and Robert Zawłocki, 2:471-547. Warszawa: Wydawnictwo C.H. Beck, 2015.

\section{A GLOSS FOR THE JUDGEMENT OF THE SUPREME COURT OF 22 JUNE 2017, FILE REF. NO. IV KK 189/17}

\section{Summary}

In this gloss, the author offers a mostly favourable commentary on the content of the judgement of the Supreme Court of 22 June 2017, file ref. no. IV KK 189/17, which provides a backdrop for a discussion of the recent legislative changes made to Article 76 of the Criminal Code that formed the basis for the said judicial decision. The relationship between this provision and Article 108 of the Code is discussed in the context of the amendments, the doctrine and case law. The article also addresses the possibility of including a conditionally suspended custodial sentence in a concurrent sentence after the probation period is over and the expiry of the period referred to in Article $75 \S 4$ of the Criminal Code.

Key words: expungement; conditional suspension of penalty; imprisonment; concurrent sentence; cumulative penalty.

Translated by Tomasz Pałkowski

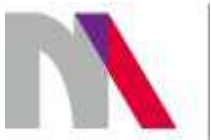

The preparation of the English version of Roczniki Nauk Prawnych (Annals of Iuridical Sciences) and its publication in electronic databases was financed under contract no. 836/PDUN/2018 from the resources of the Minister of Science and Higher Education for the popularization of science. 